\title{
PIMP MY ANTIBODY
}

\section{Antibody therapies have had more than their fair share of crashes. But designers are at work on faster, fancier new models, finds Erika Check.}
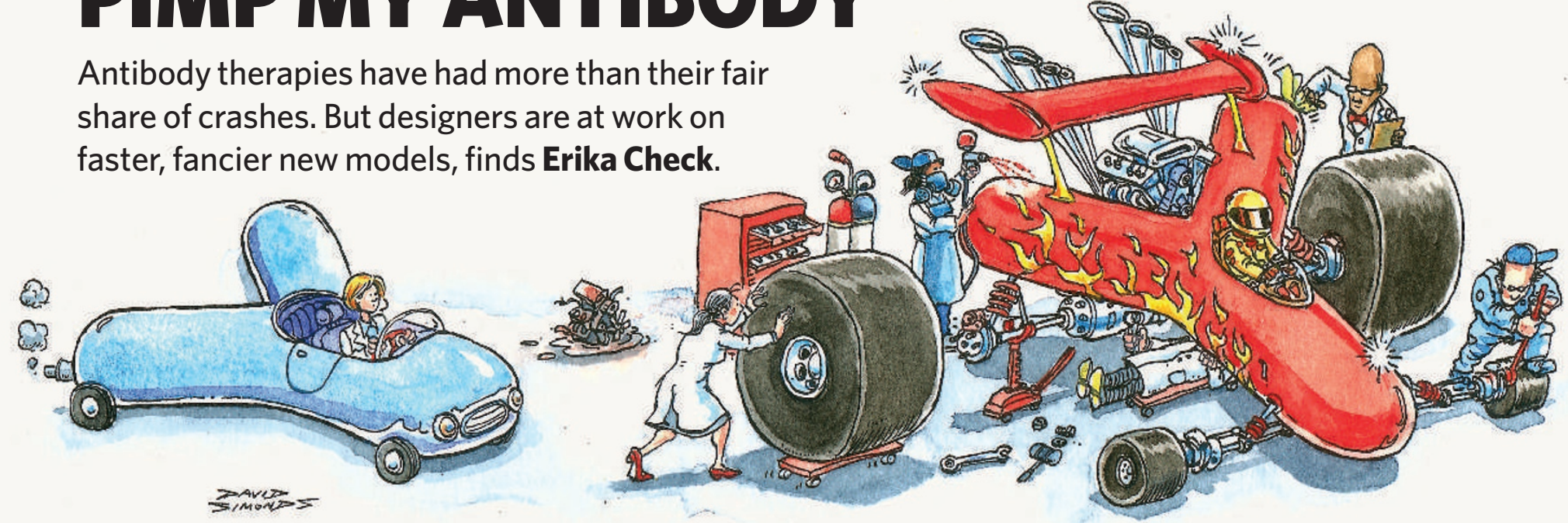

Y ou know the scene. The mechanics are in the body shop tinkering with their toys, revving things up. They're reworking big ends, stripping machines down to the basics, welding the back half of one to the front half of another in search of something new. They're after something unexpected, something flashy, something noone else has but everyone will want. It has to be streamlined; it has to be powerful; it has to be fast. And because these mechanics are customizing the design of medically important antibodies - not just pimping up their dragsters and low-riders - it also has to be very reliable and extremely safe.

The first therapeutic antibody, a mousederived molecule introduced in 1986, succeeded in blocking the normal immune attack on transplanted organs. But this was a jalopy by today's standards, and such molecules have already been through two major redesigns. In the first, scientists developed 'humanized' antibodies: safe, efficient molecules that more closely mimic antibodies made by the human body. In the second, companies worked out how to mass produce them, making antibodies serious contenders in the drug market.

Now antibodies are being souped up for a third time, and this time the result is set to be more radical. During the next decade, researchers and drug companies hope to introduce a new convoy of antibody drugs that is safer to patients and more lethal to pathogens or destructive cells. Many members of this new breed are fragments of antibodies that can reach targets that whole antibodies cannot. Some are proving useful for treating diseases once thought to be way beyond antibodies' range.

The latest spruce-up is partly motivated by rapid recent progress in biology. Scientists now understand more about how antibodies interact with their target molecules and how they recruit the body's own defences to help eliminate them. This knowledge can be converted into more effective therapies.

The redesign is also inspired by some very public disasters that have occurred during the past few years. In 2005, Biogen Idec, based in Cambridge, Massachusetts, and Elan, in Dublin, Ireland, were forced to temporarily remove Tysabri - an antibody intended to treat multiple sclerosis - from the US market after it was linked to a rare infection that can be fatal. And last year, six volunteers ended up in intensive care after taking an experimental antibody drug made by the now-insolvent German company TeGenero ${ }^{1}$.

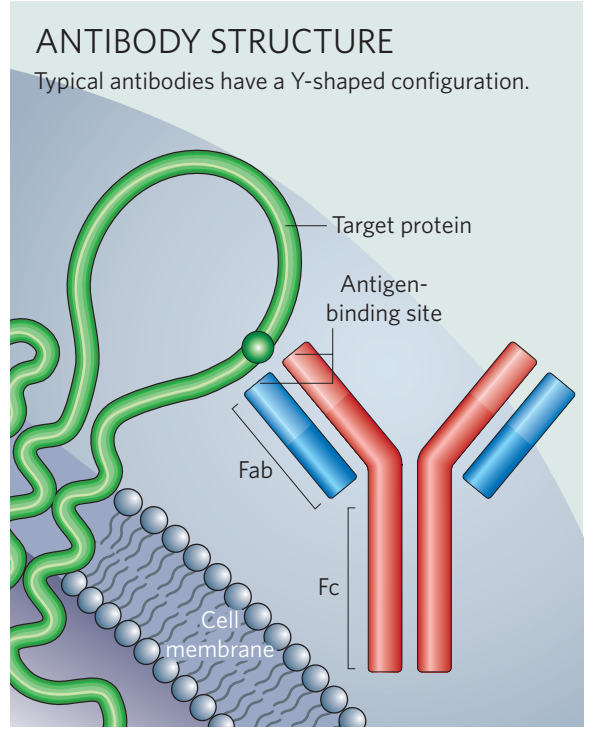

These failures have prompted caution in the design, trial and sale of antibody drugs. Biogen Idec and Elan relaunched Tysabri last July under a tightly controlled programme so that it can track and respond to any suspected side effects. And the scientists behind TeGenero's approach are now looking to treat patients' cells outside the body, which they hope will sidestep the problems caused when their antibody was delivered straight into the bloodstream. "There is definitely a consensus that if you are giving antibodies to patients you should be jolly cautious," says Richard Begent, a doctor and researcher at Royal Free and University College Medical School in London, UK, who helped investigate what went wrong in the TeGenero trial.

\section{Revving up research}

In the early 1990s, drug companies were dubious about antibodies because some of the earliest candidates didn't work, and because they are large molecules that are expensive and difficult to make. It took the blockbuster success of drugs such as rituximab - the first antibody approved to treat cancer in 1997, developed by Genentech and IDEC Pharmaceuticals - to coax major drug companies to take a second look.

Antibody therapies have proved successful in part because they work against some diseases for which treatment options are scarce, such as cancer. They also make money. “There's nothing like success in the marketplace to get pharma to look at something really hard," says Simon Moroney, co-founder and chief executive of the fifteen-year-old protein-design company MorphoSys, of Martinsreid in Munich, Germany. Today, 21 antibodies are approved for sale, and the market is projected to be worth US $\$ 22$ billion by the end of this year. Genentech, based 
in South San Francisco, California, has grown from a small, cash-strapped start-up to a multibillion-dollar biotechnology giant on the strength of antibodies. Most major pharmaceutical firms now have partnerships or in-house discovery units devoted to antibody therapies, and much of the basic research is being done by them and in biotech companies.

It may seem audacious for scientists to try to improve on our own antibodies, which are elegantly constructed to recognize and eliminate harmful cells and organisms from the body. Natural circulating antibodies have a structure that resembles a Y (see 'Antibody structure'). The portion of the antibody corresponding to the arms of the $\mathrm{Y}$ is the Fab region. These arms feature 'hands' and, just like the myriad shapes and sizes of human hands, the Fab region's hands come in an endless variety of forms that each recognize and dock with one of billions of target molecules, such as structures on invading pathogens.

Once docked, the antibody's business end - the Fc region - goes to work. This portion corresponds to the tail of the Y. It sends signals to the body's own assassins - cells and molecules that destroy whatever the antibody has latched on to.

\section{Bits and pieces}

The Fab and Fc regions were both thought to be essential to antibodies' ability to seek out potential threats within the body and mark them for annihilation. So many scientists scoffed when, in 2000, a 28-year-old researcher named Ian Tomlinson and his colleague Gregory Winter, based at the prestigious Medical Research Council's Laboratory of Molecular Biology in Cambridge, UK, founded a company on what seemed like a hopeless premise. (Tomlinson even left the institute to focus on this project.) Winter's team had shown that it could create 'domain antibodies' consisting of only a small stump of the Fab region, and completely lacking an $\mathrm{Fc}$ region ${ }^{2}$. Tomlinson and Winter claimed that these 'abbreviated' antibodies would be able to follow paths that are off-limits to whole antibodies, such as passing through the gut into the bloodstream. Whole antibodies are too large to penetrate the gut lining and must be injected directly into the blood.

Seven years later, this play looks quite smart. It turns out that the Fc region of an antibody, which marks cells or molecules for destruction, isn't always necessary. In some cases, binding of the Fab region prevents a molecule

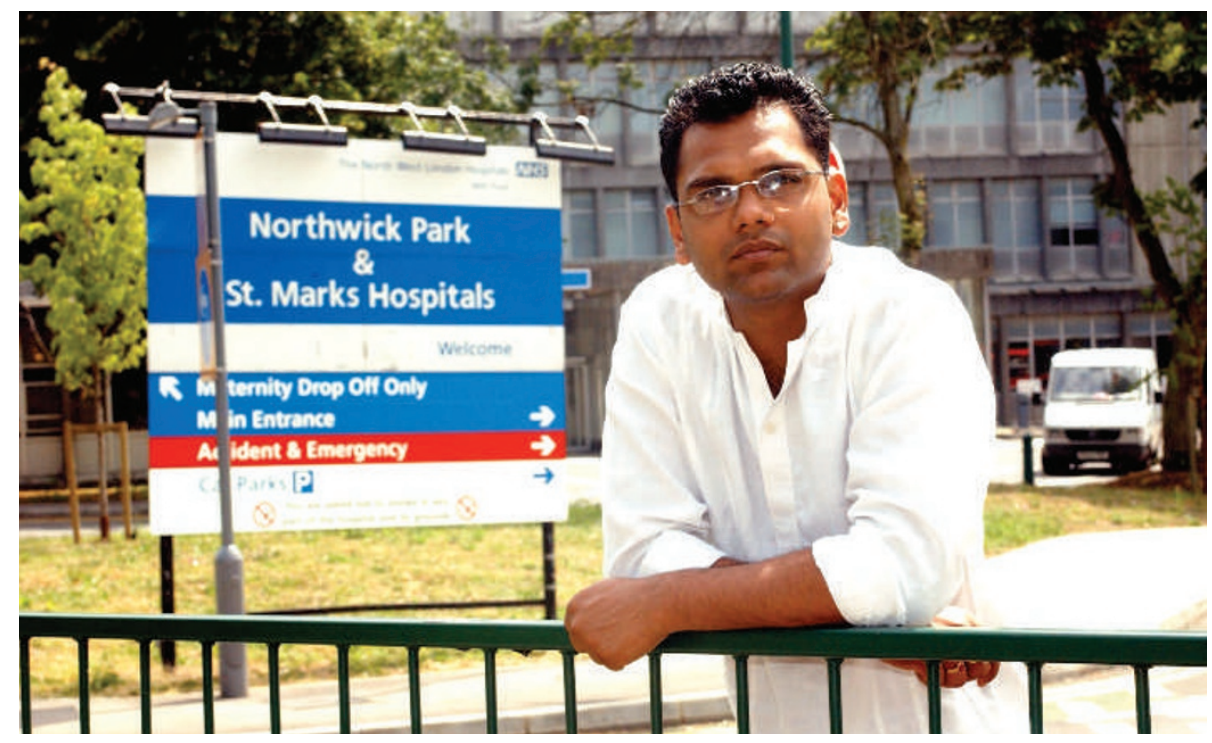

The disastrous trial of TeGenero's experimental antibody at Northwick Park holds important lessons.

from performing a detrimental action, making its annihilation unnecessary. (Indeed, the Fc region can even be dangerous; reactions mediated by the Fc portion of the TeGenero antibody are thought to have had a role in its extreme side effects.)

Domantis, the company founded by Tomlinson and Winters and based in Cambridge, says it has shown that its domain antibody against a molecule known as tumour necrosis factor alpha is effective in animal models of rheumatoid arthritis and chronic lung disease, and preclinical trials are under way. Last December, Domantis was bought for $£ 230$ million (US\$461 million) by drug giant GlaxoSmithKline.

The acquisition of Domantis is a prominent endorsement of a burgeoning area of innovation: using pieces, parts or combinations of antibodies. Companies and academic researchers are now testing all sorts of pared-down or piecedtogether antibodies in the hope that they will reach targets inaccessible to the whole molecule, or hit already accessible targets more effectively.

The varieties are seemingly endless. Some consist of the entire Fab region; six such therapies have been approved by the US Food and Drug Administration (to prevent blood clotting, for example, or treat snake bites) and more are in clinical trials. Others are just a tiny portion of the Fab region, consisting of little more than a targeting domain — that is, a single hand one of the antibody's arms. Some such fragments have been linked together in doublets or triplets that bind to multiple targets or to different regions on the same target, thus binding it more tightly. Domantis is working on such linked antibodies. Even more fragments have been connected to other molecules such as stabilizing agents or drugs.

Scientists in Maryland and California, for example, have glued together small segments of a Fab region that attaches to a receptor on human cancer cells. They linked it to the chemotherapy agent doxorubicin in order to target the drug exclusively to cancer cells ${ }^{3}$. The question now is how effective this and the many other innovative structures will be. Most scientists suspect that this will depend on the disease being treated and the specific structure of the molecule designed to treat it.

\section{Back-seat driver}

Many researchers are focusing on the front portion of the antibody, but there is also increasing interest in the Fc region. The importance of this region was famously shown five years ago when a group of researchers based in France published a study on rituximab. This antibody binds to and wipes out B cells, which multiply in certain types of cancer. Rituximab has been a miracle cure for some patients, but fails to work in $30-50 \%$ of people with particular lymphomas.

The researchers divided patients on rituximab into groups on the basis of genetic variations in particular receptors that bind the $\mathrm{Fc}$ region and help to kill whatever the antibody has bound to. One group had receptors that bind the antibody tightly, and another had a form that bind it more loosely. Of those patients with the tighter-binding form, $90 \%$ benefited from rituximab, compared with only $50 \%$ of those with the looser-binding variant ${ }^{4}$. This 
was a dramatic demonstration that interactions involving an antibody's back end can be crucial to its effectiveness - "a pretty big step," says Greg Lazar of the biotechnology company Xencor, of Monrovia, California.

Researchers and companies are now attempting to modify the rear end of antibodies so that they bind their receptors more strongly and boost a patient's immune response. Xencor, for instance, has retooled its entire business model to focus on this idea. The field is rife with competition, and companies are doing everything from changing the structure and surface properties of the $\mathrm{Fc}$ region to altering its amino-acid sequence. It's not clear whether these attempts will work. But it won't take long to find out, because clinical trials of antibodies with modified Fc domains have already begun.

Until now, many such therapies have been aimed at cancer cells, which have their own unique protein signature an antibody can latch onto. Autoimmune disease has been another focus, because antibodies can interfere with specific overactive proteins in the immune system.

\section{New directions}

But now companies are broadening their sights. One of the most intriguing examples of this began about ten years ago, when scientists at Genentech were trying to treat a condition known as peripheral neuropathy by injecting patients with a form of nerve growth factor, a protein that was lacking in the neurons of their skin. The company stopped developing the drug because it wasn't working well and because of potential side effects. Patients had reported pain at the injection site and throughout their entire bodies.

In 2001, Genentech spun out all of its efforts to develop treatments for the nervous system. Arnon Rosenthal, the Genentech executive who left to run the spin-off company, was

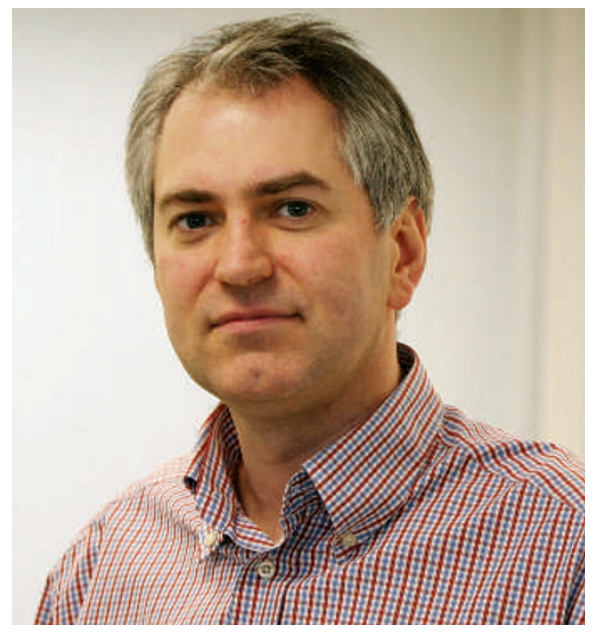

Ian Tomlinson backed the idea that fragments of

antibodies could be effective on their own.

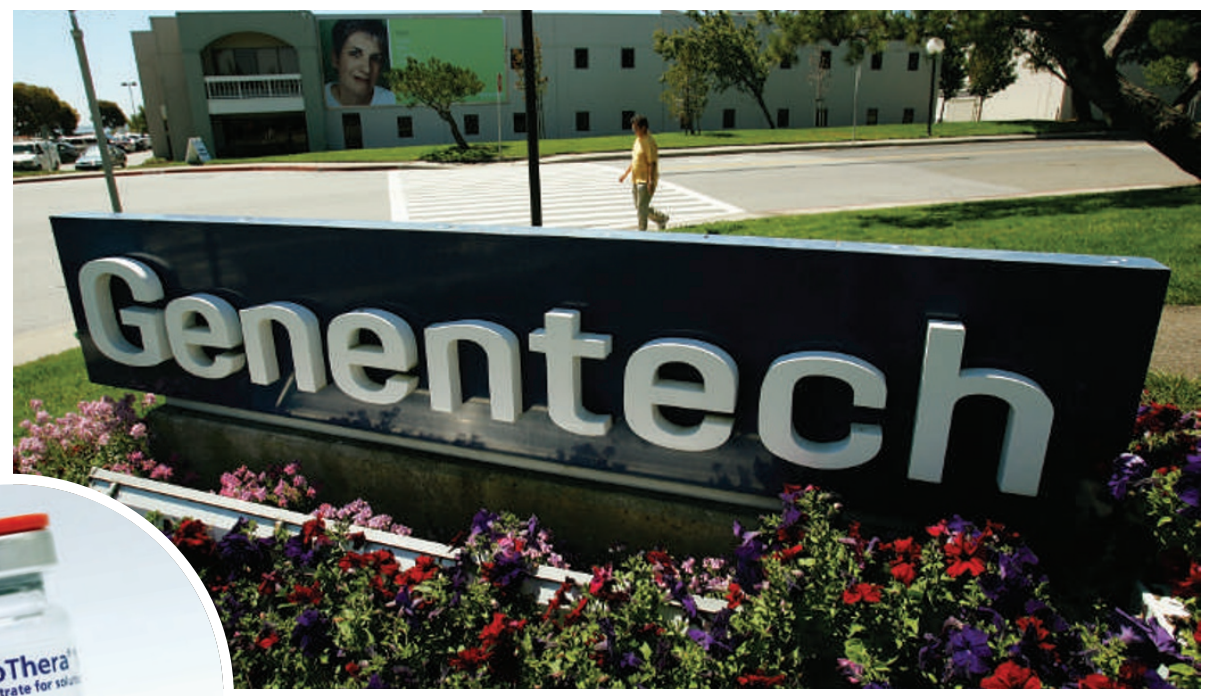

Genentech's success with rituximab drew big drug companies to antibody research.

intrigued by the perplexing side effect of the nerve growth-factor trials. If injecting the protein caused pain, he wondered whether blocking the protein might relieve it. Some thought this idea wildly impractical, because nerve growth factor is thought to be essential for the survival of neurons in the central nervous system.

Nonetheless, Ronsenthal's company, Rinat Neuroscience, decided to test the hunch - after all, the pain market is vast, and no major pain drugs had been developed in almost a decade. The company produced an antibody to block nerve growth factor and tested it in animal models of cancer and arthritis pain, then in human volunteers. Last May, one month after Rinat was acquired by the drug giant Pfizer, company scientists reported to a meeting of the American Pain Society that a single injection of the blocking antibody alleviated arthritis pain in 79 patients for up to two months.

"Tysabri served
as a warning that
antibodies for
nervous-system
conditions can
have unpredictable
results."

Earlier attempts to treat nervous-system disorders with antibodies ran into difficulties. Biogen Idec and Elan's troubled drug Tysabri, for instance, is intended to prevent the immune cells that cause nerve damage in multiple sclerosis from entering nervous tissues. The antibody binds to a protein known as integrin alpha- 4 on these cells. But it had been on the market only a few months when the company had to pull the drug after two patients taking it developed a rare brain infection. The companies conducted a thorough - but inconclusive - investigation to try to discover what could be causing the infections.

The Tysabri episode served as a warning that antibodies for nervous-system conditions can have unpredictable results - but it hasn't slowed the race to find them. Alzheimer's disease is a particularly attractive target, because the potential drug market is huge. The toxic protein aggregations that cause this brain disease could, in theory, be neutralized or destroyed by an antibody.

One complication is that antibodies are large, and so rarely cross the protective blood-brain barrier. Even so, one clinical trial found hints of efficacy. The trial, conducted by Elan in conjunction with Biogen Idec, used a vaccine designed to spur production of patients' own antibodies against the toxic proteins. The trial was halted because it caused dangerous brain infections in some patients ${ }^{5}$ - but autopsy reports suggested that the vaccine did shrink protein clumps in the brain ${ }^{6}$. Moreover, the company says that some treated patients lived more independently than did those in the control group.

Other companies have hurried to start work on better antibodies against Alzheimer's disease - ones that deliver antibodies directly into the body rather than trying to stimulate their production with a vaccine. Elan is farthest ahead, and is running a 240-patient trial in conjunction with Wyeth that is expected to wrap up next year. Other major companies, such as Merck and Eli Lilly, aren't far behind.

Should one of these treatments work, it would mark a watershed in Alzheimer's disease treatment, and a major milestone in the expansion of diseases that might be treated by antibodies. Designers are already thrilled by the new mileage promised by their pimped-up antibodies - and are all too eager to take them for a spin.

Erika Check is a senior reporter for Nature in San Francisco.

1. Hopkin, M. Nature 440, 855-856 (2006)

2. Ward, E. S., Güssow, D., Griffiths, A. D., Jones, P. T. \& Winter, G. Nature 341, 544-546 (1989).

3. Nellis, D. F. et al. Biotechnol. Prog. 21, 221-232 (2005).

4. Cartron, G. et al. Blood 99, 754-758 (2002).

5. Check, E. Nature 422, 370-372 (2003).

6. Nicoll, J. A. R. et al. Nature Med. 9, 448-452 (2003). 